\title{
A study-of-Religion(s)-Based Religion Education: Skills, Knowledge, and Aims
}

KARNA KJELDSEN ${ }^{1}$

$\approx$ Different approaches to religion education have been in place for a long time or developed more recently to meet growing religious and cultural plurality in European countries and schools. In this article, I summarise and discuss basic principles for a study-of-religion(s) approach to religion education, adding arguments and perspectives from critical theories about education in general. I shall also argue that national curricula for, respectively, religion education in Sweden and History in Denmark indicate that analytical-critical skills can be a central part of religion education in elementary and lower secondary public schools. The structure of the article is based on a modified version of the 'map of history' developed by the scholar of education and history education Rosie Turner-Bisset who has formulated principles for teaching History in primary schools. The model will be used as a framework, for systematising and discussing key principles of a study-of-religions approach to religion education with reference to three categories: 1) attitudes, 2) skills and concepts, and 3) knowledge.

Keywords: citizenship education, learning about/learning from religion, religion education, study of religions 


\section{Na religiologiji temelječe religijsko izobraževanje: veščine, znanje in cilji}

KARNA KJELDSEN

$\propto$ Različni pristopi k religijskemu izobraževanju so prisotni že dolgo časa ali pa so se razvili pred kratkim v luči rastoče religijske in kulturne pluralnosti v evropskih družbah in šolah. V prispevku povzemamo temeljna načela na religiologiji temelječega pristopa k religijskemu izobraževanju in o njih razpravljamo, dodajamo pa tudi argumente in perspektive splošnih kritičnih teorij o izobraževanju. Zagovarjamo tezo, da nacionalna kurikuluma za religijsko izobraževanje na Švedskem in zgodovino na Danskem dokazujeta, da so lahko analitično-kritične veščine osrednji del religijskega izobraževanja v javni osnovni šoli. Struktura članka temelji na modificirani različici 'zemljevida zgodovine', ki ga je razvila strokovnjakinja za edukacijo in poučevanje zgodovine Rosie Turner Bisset in v njem oblikovala načela za poučevanje zgodovine v osnovni šoli. Model uporabimo kot okvir za sistematiziranje in razpravo o ključnih načelih na religiologiji temelječega religijskega izobraževanja glede na tri kategorije: 1) stališča; 2) veščine in koncepti; 3) znanje.

Ključne besede: državljanska vzgoja, učenje o religijah/od religij, religijsko izobraževanje, religiologija 


\section{Introduction}

In national and international discussions on religion education (RE) in public schools, the questions of whether and how RE should focus on various extra-academic aims remain central. Questions are often formulated in terms of whether the pupils should learn not only about religion but also from religion. What is less clear, however, is what these categories mean and how learning from religion is different from learning religion/education into religion, sometimes used as categories for confessional RE (Alberts, 2008; Kjeldsen, 2016; Teece, 2008, 2010). Many politicians, RE researchers, and teachers still argue that the overall aims also of, in principle, non-confessional RE in public schools should involve various kinds of extra-academic aims and thus include learning from religion. Over the previous two decades, these discussions have been related to political discourses on citizenship education and intercultural/interreligious dialogue as means of meeting challenges such as intolerance, discrimination, and lack of social cohesion due to the increasing religious and cultural plurality in European countries and schools (Council of Europe, 2002; Jackson, 2009, 2014; Willaime, 2007). International organisations, including the Council of Europe, the Organization for Security and Cooperation in Europe (OSCE), and the United Nations, have been very active in promoting and developing projects and political recommendations on how member states should implement citizenship and intercultural education in schools. According to these organisations, teaching on 'religious and non-religious convictions' should be a central part of this education in order to foster social cohesion, tolerance for difference, and respect for human rights (Council of Europe, 2002, 2008a, 2008b; OSCE, 2007; UN, 2006). ${ }^{2}$ Several RE scholars from different academic fields have participated in these or related projects and have proposed ways in which RE can contribute to these aims. They especially recommend didactic approaches focused on intercultural and/or interreligious dialogues, including different ideas on learning from religion (e.g., Jackson, 2008, 2014; Keast, 2007; Miedema, Schreiner, Skeie, \& Jackson, 2004; Weisse, 2007). However, as research from different countries show, discourses on citizenship education and learning from religion are also linked to political and ideological efforts to use schools and RE as key instruments to transmit and (re)socialise the pupils into what is seen as the traditional cultural and religious norms and values (Jensen, 2013; Jensen \& Kjeldsen, 2013; Jödicke, 2013). Based on their research on RE, scholars of the study of religions including Tim Jensen,

2 See Jackson, 2008, and Jensen and Kjeldsen, 2014 for an overview on these initiatives. 
Wanda Alberts, Bengt-Ove Andreassen, Jenny Berglund, Katharina Frank, and Christoph Bochinger, ${ }^{3}$ have criticised several aspects of these approaches and the ways in which RE is implemented in many if not most European countries. They are particularly critical of the tendency to use and think of RE as a 'special' school subject, which should contribute to different kinds of political, existential or moral extra-academic aims. Instead, they have argued that RE ought to be a normal school subject, and as such, be based on the academic university subject: in this case, the academic-scientific study of religion. In a number of publications, they have reflected on essential principles for this kind of RE (e.g., Alberts, 2007; Andreassen, 2016; Berglund, 2010; Frank, 2013, 2014; Frank \& Bochinger, 2008; Jensen 2008, 2011).

In this article, I summarise and discuss basic principles for a study-ofreligion(s) approach to $\mathrm{RE}$, adding arguments and perspectives from critical theories about education in general. I shall also argue that national curricula for, respectively, RE in Sweden and History in Denmark indicate that analytical-critical skills can be a central part of RE in elementary and lower secondary public school. The article mainly draws on the RE research and reflections conducted by study-of-religion(s) scholars. References will also be made to my research on how Christianity is discussed and represented in political and public debates in Denmark, national curricula, textbooks, and the intended teaching of RE teachers (lesson plans, syllabi, other teaching material, etc.) in primary and lower-secondary schools in Denmark (Kjeldsen, 2016, 2019). ${ }^{4}$

The structure of this article is based on a modified version of the 'map of history' developed by the scholar of education and history education Rosie Turner-Bisset (2005, p. 20). In this model, she formulates important principles for teaching history in primary schools regarding 1) attitudes towards the discipline, 2) syntactic knowledge (processes and skills), and 3) substantive knowledge (concepts). To teach history well in schools, Turner-Bisset argues that a deep understanding of History as an academic discipline is required, including knowledge of the facts and concepts of the discipline and the frameworks that inform historical enquiry. History teachers (and pupils) should have knowledge about how to study history (i.e., methodological and theoretical knowledge and skills) and a set of attitudes towards the subject, for example 'history is an enquiry-based discipline' (ibid.). According to this model, children should

3 These scholars are members of the European Association for the Study of Religions (EASR) Working Group on Religion in Public Education, established in 2007 by Wanda Alberts and Tim Jensen.

4 The data for this part of the study consist of collected documents from teachers in 15 classes from the 3 rd grade, 14 classes from 6th grade and 14 classes from 9th grade, and it covers in total 37 schools from different areas in Denmark. 
investigate primary sources, question them rigorously, set them into context and be able to present their produced knowledge. I find these principles highly relevant for a study-of-religions-based RE. The model will be used as a framework for systematising and discussing key principles of a study-of-religions approach to RE with reference to three categories: 1) attitudes, 2) skills and concepts, and 3) knowledge.

\section{Attitudes towards RE and the Study of Religion(s)}

Proponents of a study-of-religions approach to RE argue that it should be a standard, compulsory school subject. A school subject in line with what Alberts (2007) has defined as 'integrative RE', Jensen (2011) as 'secular RE' (or 'religion education') and Frank and Bochinger (2008) as 'Religionskunde'. In order to make the subject compulsory, it should, as discussed by especially Jensen, Andreassen, and Alberts be able to meet the criteria for a compulsory school subject dealing with religion, i.e., it must be objective, critical, and pluralistic (Alberts, 2010, p. 283; Andreassen, 2014, pp. 265-266; Jensen, 2011, p. 141). ${ }^{5}$ This means that RE must be emancipated from theology and religious interests and be the responsibility solely of educational authorities. Well-educated teachers, who, in addition to their pedagogical and educational expertise, are educated in the academic study of religion, should teach the subject. It also implies that the course name, curricula, and content cannot favour a specific religion with references to cultural and historical arguments, as is often the case with Christianity in European countries. As pointed out by RE scholars, linking Christian values with democratic and national values and heritages ostracises people with other or no religious outlooks and (re)produces boundaries between a Christian 'we' and 'others'. Furthermore, specific countries and Europe as a whole are not solely grounded in Christian values and ideas, and schools cannot be expected to consolidate only one tradition or maintain historical power structures (Alberts, 2007, p. 368; Andreassen, 2014, p. 277; Berglund, 2013, pp. 172-173; Jensen, 2005, pp. 72-73). Another crucial attitude is that in educational and scientific settings, religions should be studied as human-socially and culturally constructed, negotiated and changing phenomena from a non-religious perspective. This means, inter alia, that teaching or representations on religions include insider perspectives, but is marked by an outsider perspective based on analyses and explanations developed in the academic study of religions and

5 This is stated in the rulings of the European Court of Human Rights in the case Folgerø and others vs. Norway (2007). See Andreassen (2013) and the complete verdict at https://hudoc.echr.coe.int/ eng\#\{\%22itemid\%22:[\%22001-72492\%22] $\}$ 
other human or social sciences (Alberts, 2007, p. 377; Andreassen, 2016, pp. 48-50; Frank, 2013; Jensen, 2005, 2008, 2011).

One of the tenets of the kind of RE propagated by the named scholars is that the school subject should not have different kinds of explicit political, existential or moral extra-academic aims. They find it problematic that RE should contribute directly to political-social aims, such as citizenship education, and thus be used as a key instrument in identity politics and 'culture wars', not least because that often implies that the majority religion (a variant of Christianity) is given a special status in the subject and in the general education and formation (German: Allgemeinbildung) of the pupils (Alberts, 2007; Andreassen, 2014; Berglund, 2013; Jensen, 2015; Jensen \& Kjeldsen, 2013; Kjeldsen, 2016). Tim Jensen, for one, has argued that, although there may be positive political and social side effects of RE, this should not constitute the primary justification for RE, and that RE ought to be relevant in all contexts, including future contexts, where the present problems and challenges may be irrelevant or may have changed in unexpected ways (Jensen, 2008, p. 131). Moreover, as research indicates, it is very difficult to evaluate whether and how RE has actually contributed to extra-academic attitudes or competencies; to what extent pupils will continue to have and use these, and whether RE will generate the expected socio-cultural and political effects in the long run (e.g., Ipgrade, 2012; Sjöborg, 2013). Scholars of pedagogy and education, Dietrich Benner (e.g., 2005) and Gert Biesta (e.g., 2014) have expressed similar criticism of educational discourses on citizenship. In their view, there is too much focus on unrealistic expectations when it comes to school-based citizenship education as a means to solve political problems. One of their arguments is that these strategies tend to overlook the fact that political and cultural challenges depend on broader structural, economic, and social conditions and solutions, and thus cannot be solved by individuals through learning processes. Another argument is that many politicians and school authorities understand citizenship education in social terms as socialising children, especially immigrant children, into existing political, religious, or social values and norms. For Biesta, citizenship is a political identity understood as the readiness or ability to take political actions that challenge the status quo when needed (Biesta, 2013, pp. 13-19). In line with this view, Benner argues for a non-affirmative approach to education in which the younger generations learn how to discuss critically, problematise, challenge, and, if possible, how to find alternatives to dominant values and attitudes (Benner, 2005).

Study-of-religion(s)-based RE scholars are also critical of approaches to $\mathrm{RE}$ which focus on intercultural or interreligious dialogue, and/or have as a stated aim that the pupils should learn from religions in an existential, moral or 
religious way. Often, such approaches require pupils to express their existential or religious outlooks. However, some research indicates that publicly defined ideas about social identities (cultural or religious) and 'us and them' can be enhanced or even learned in schools when pupils are expected to discuss their own religious or existential outlooks (Buchardt, 2014). Moreover, as pointed out by Andreassen (2016, p. 19) and Frank (2013, p. 56), focusing on these topics can be a violation of the pupils' private sphere. Andreassen also emphasises that it becomes even more problematic if the subject includes evaluations or exams. In my research, I found that some teachers included personal questions in the examination questions. Examples included 'Discuss if you see yourself as a selfish person or one who "love[s] thy neighbour" (in a Christian way)'; 'Discuss whether you are an atheist or believe in God'; and 'What does "love of thy neighbour" mean to you?' (Kjeldsen, 2016, p. 253).

As pointed out by Andreassen, it is difficult to see how pupils' attitudes, views of life and existential questions can be evaluated based on professional, explicit criteria. Furthermore, he refers to research conducted in England by Nigel Fancourts (2005) demonstrating that many pupils have the impression that, in order to have good evaluations, they have to show that they have become better, moral humans by learning from religions (Andreassen, 2016, p. 205). Another criticism put forward by, Alberts (among others) is that approaches to $\mathrm{RE}$ that attempt to combine non-confessional $\mathrm{RE}$ with the idea of learning from religion in a religious or existential way sometimes fall back into what could be categorised as religious models (Alberts, 2007, p. 359). ${ }^{6}$ This criticism also applies to life-philosophical/existential approaches, ${ }^{7}$ which often take a liberal-protestant/existential theological approach to religion as a starting point. In these approaches, existential questions and answers or Paul Tillich's notion of 'ultimate concerns' (Tillich, 1966, pp. 15-28) are seen as the essence of all religions and an ontological fact. This notion of religion is used as an argument for making pupils' existential questions the point of departure in RE and that the pupils can learn from religions in an existential way while remaining in a secular framework (Andreassen, 2008, pp. 97-109, 266; Berglund, 2013, p. 179; Jensen, 2013, p. 42). My studies on teachers' intended teaching, national curricula, and textbooks clearly show that such approaches can end up in a grey area between learning about religion and learning religion (Christianity), irrespective of the teachers' intentions. One important finding was that while other religions are

6 Other research also indicates this problem, see for example Conroy et al., 2013, pp. 43, 46.

7 Life philosophy (German Lebensphilosophie) in Denmark is inspired by the Danish theologians, N. F. S. Grundtvig and K. E. Løgstrup and liberal-existential theologians such as Paul Tillich. Life philosophy is put forward as the overall perspective in the official curriculum and guideline for $\mathrm{RE}$ in the elementary and lower-secondary school in Denmark. See also Böwadt, 2009. 
represented from an outsider perspective with a focus on practice, Christianity is represented from an insider perspective and related to the life-world of the children, so-called universal existential questions and national-cultural values. In this way, Christianity is depicted as more relevant for the children's lives than other religions, and the only religion they are expected to learn from (Kjeldsen, 2016, 2019). This kind of RE is an example of what Jensen and Kjeldsen have termed 'small-c confessional RE', i.e., RE formally dissociated from a specific religious confession but still based on a religious understanding of religion, and with an explicit or implicit aim of promoting religion, or religion-based values (Jensen \& Kjeldsen, 2013, p. 188). ${ }^{8}$

Due to these problematic aspects, proponents of a study-of-religions approach to RE suggest that the aim of RE primarily should be to contribute to the developing of the pupils' analytical and critical thinking competencies and knowledge. This includes the ability to analyse, discuss, and explain religious and non-religious discourses on religion(s) and examine religious diversity in relation to social and historical developments, power, politics, social conflicts, and other factors (Alberts, 2008, 2010; Andreassen, 2016; Berglund, 2013; Frank, 2014; Frank \& Bochinger, 2008; Jensen, 2011). These analytical and critical thinking competencies and scientific-based knowledge may contribute to the general education and formation of the pupils, including citizenship education understood in line with Benner and Biesta's critical pedagogic and educational theories. However, the latter cannot be tested or guaranteed.

\section{Skills and concepts: Theoretical and methodological theories and reflections}

A central element of a study-of-religion(s)-based approach to RE is that the pupils learn how to use theoretical and methodological approaches and terminology pertaining to the academic study of religion(s). In this way, RE can contribute to the development of general skills, such as the ability to describe, analyse, and contextualise primary and secondary sources. Pupils should also learn to systematise, categorise, and compare different aspects of religions (i.e., myths, rituals, authority, and gender). When the pupils are ready for it, the teaching can also include theories and methods to analyse different discussions on how religion(s) can be related to societal changes, minority-majority issues, identity discourses, ethics, politics, conflicts and ideology. Another critical skill is the ability to identify and compare insider and outsider representations and

8 The term 'small-c confessional RE' is inspired by the distinction about theology and theology-like or religious studies of religion proposed by scholar of the study of religions, Donald Wiebe (1984). 
sources and critically analyse them. These skills can contribute to the ability of the pupils to analyse and discuss all religions and religion-related issues from a methodological agnostic and distanced perspective, regardless of their own religious, anti- or non-religious outlooks (Alberts, 2017, p. 181). It is necessary to underscore that when pupils use theoretical and methodological approaches pertaining to the study of religion(s), they will be producing knowledge themselves and not just learning about religious topics.

According to scholars of religion, Armin W. Geertz and Russel T. McCuthenon (2000), the academic study of religion(s) has been marked by different 'turns', including 'the linguistic turn' (e.g., Jensen, 2003), 'the cultural turn' (e.g., Gilhus \& Mikaelsson, 2001), 'the social turn' and post-colonial and feminist criticisms (e.g., Geertz, 2000, 2015). These 'turns' have given rise to self-critical and new theoretical reflections on concepts, such as 'religion' and 'world religions', and reflections on how to best represent and compare religions. Many of these self-critical reflections and developments are relevant to RE as a school subject. Proponents of a study-of-religion(s) approach to RE argue that a central part of RE should be the deconstruction of the concepts of religion and world religions, as well as other concepts, such as culture and ethnicity (Alberts, 2007, p. 381; Andreassen, 2016, p. 50-51; Frank, 2013, pp. 77-80; Jensen, 2005, p. 72). Pupils should be introduced to some of the basic criticism on how the western liberal-Christian notion of religion has framed the dominant understanding of the concepts on religion and world religions, and how other religions have been constructed and evaluated hand in hand with colonisation and Christian mission (Asad, 1993; King, 1999; Masuzawa, 2005; Said, 2003). An important insight for pupils is that notions of and approaches to religion centred on 'belief' and 'ultimate concerns' tend to overlook the fact that what scholars and others call religion means different things to different people and cannot be separated from other cultural spheres (e.g., Jensen, 2003; Lincoln, 2006; Luther, 2000; McCutcheon, 2015). This criticism and deconstruction should also be part of the teaching of the younger pupils in a simplified way. They can attempt to work out their own and compare definitions on religion, and they can analyse and discuss what the concept of world religion implies. Older pupils can analyse which understanding of religion and other related concepts dominate public and political discussions, and discuss the possible consequences of this use. 


\section{Knowledge: Religions as internally diverse and multi-dimensional phenomena}

A study-of-religion(s)-based RE makes a variety of religious ideas/traditions from different geographic and temporal contexts a central part of the content. Other relevant content includes new religions, spirituality, civil religion, criticisms of religion, non-religious outlooks, and different philosophical traditions. Ethical and existential issues can also be a part of RE if they are approached from a more distanced perspective than in the case of the different life-world approaches (Alberts, 2007, pp. 376-379; Jensen, 2005). An essential principle in the study of religion(s) and RE is to represent and study religions as internally diverse, innovative, dynamic, and changeable phenomena. Postcolonial and feminist criticisms have contributed to a growing awareness in the study of religion(s), that religions often have been studied and represented with a focus on texts, institutions and official doctrines and practices. This has given rise to studies on how different aspects of religions, for example, myths, doctrines, and rituals are constructed phenomena, which produce and legitimise hierarchy structures, authority and social roles. Studies on the lived religion of different groups and individuals, as well as how unofficial forms of religion can differ from the official versions are also ways to study and represent religions in a more complex and nuanced way (Lincoln, 1989; McCuthenon, 200o; Mikaelsson, 2004). A growing new field investigates how material objects, spaces, and bodily aspects are central parts of religious traditions and how people practice and conceive their religions. Another focus is on how materiality plays a vital role in the construction, maintenance and contesting of authority, social roles, and ideologies (Feldt \& Høgel, 2018; Morgan, 2010). These insights are highly relevant for RE. In order to prevent schools from conveying one particular interpretation of a religious tradition as the authoritative one, RE must include examples of different sources that represent the voices of a variety of individuals and social groups across gender, age, minority-majority positions, and religious affiliations (Alberts, 2007, p. 379; Andreassen, 2012, pp. 92-95; Berglund, 2013, p. 49; Jensen, 2011, p. 142). Fieldwork (including online fieldwork), interviews and other anthropological or sociological methods can also be useful approaches through which the pupils themselves produce knowledge on diversity, lived religion and compare official and unofficial religion. Working with different religious objects, sounds, places and bodily aspects are also ways to illustrate that religions are more than texts, dogmatic teaching, and beliefs. It must be an overall aim for RE to represent religions in a balanced way and include historical and contemporary developments, innovation, diversity, official, 
unofficial and individual aspects, lived religion, conflicts and relations to other aspects of the society.

Apart from representing different religions as unique cultural and historical formations, RE should include cross-cultural and comparative aspects. As pointed out by Jensen (2011), this comparison must be qualified by using the terminology and principles that pertain to the study of religion(s). One important principle is to avoid comparing religions as a whole (e.g., Islam vs Christianity) as comparison of religions as massive closed systems can (re)produce stereotypes and link religions, ethnicity and cultures together in an essentialised way. In my study of RE textbooks and their teaching guidelines for the elementary and lower-secondary school, I found many examples of such problematic comparisons. A very common example is that Islam and Judaism are characterised as law-based religions, while Christianity is presented as a 'religion of love or spirit' which 'does not have any rules connected to food because all the attention is directed towards love at God and other human beings' (e.g., Mortensen, Rydahl, \& Tunebjerg, 2002, p. 60). Another important principle is that comparisons should not only focus on similarities but also on differences (Jensen \& Sørensen, 2015; Paden, 2004). Scholar of religion Aaron W. Hughes (2012) has, for example, shown how the concept of 'Abrahamic religions' is a non-academic discourse that aims to promote interreligious dialogue by showing similarities between Judaism, Islam, and Christianity. He criticises that this concept signals that an essential core and general similarities between religious ideas and practices from very different periods and geographical contexts exist. In his opinion, such comparisons cannot contribute to the knowledge of how groups and individuals from different historical, cultural, and social contexts are religious (Hughes, 2012).

\section{Is a study-of-religion(s) approach to RE possible? Examples from national curricula.}

Although an increased readiness to represent religions in a more nuanced way can be detected in RE in some countries and in other approaches to RE, many scholars, teachers and policy-makers express the opinion that a study-of-religion(s) approach to RE is not applicable in the primary and lower-secondary schools. One argument is that RE should include learning from religion(s) in various ways in order to live up to the schools' overall aims. Another argument against this approach is that it is too sophisticated for children at these grade levels. However, if we look at national curricula for other school subjects, such as History, it is difficult to see why the latter argument is 
pedagogically or educationally valid. History in Denmark is a good example. The subject is introduced in the $3^{\text {rd }}$ grade level, and after the $4^{\text {th }}$, pupils shall:

- Have knowledge about historical-critical concepts and how to find, use and evaluate sources.

- Be able to read historical primary sources and choose sources to illustrate historical issues.

- Have knowledge about terminology, concepts and historical sources.

- Be able to explain the historical-critical concepts used in the analyses of different sources (The Danish Ministry of Education, 2019a, author's translation and emphasis).

As these excerpts from the national curriculum illustrate, a central part of History, also in the lower grade levels, is that the pupils shall attain knowledge about and use theoretical and methodological methods to analyse primary sources. This clearly differs from RE in primary and lower-secondary school in Denmark. In the national curriculum, there are no aims related to theoretical or methodological issues. After the $3^{\text {rd }}$ grade level, the pupils shall be able to:

- Express themselves 'on the religious dimension ${ }^{29}$ based on fundamental existential questions and ethical principles.

- Express themselves on central biblical narratives,

- Express themselves on what Christianity is and about the central elements of the history of Christianity, including the role of the established church in Denmark.

After the $6^{\text {th }}$ grade, the pupils should be able to express themselves in nuanced ways about the same content, and after $9^{\text {th }}$ grade, the pupils should be able to:

- Relate to/or take a position on 'the religious dimension'.

- Interpret how fundamental values can be found in Biblical narratives.

- Relate to/or take a position on 'what Christianity is' and on problematic questions/issues in some of the major world religions and worldviews

- (The Danish Ministry of Education, 2019b, author's translation and emphasis).

The curriculum does not explain what is meant by the phrases, 'relate to' or 'take a position on'; it also does not place any attention to analytical and

9 'The religious dimension' is an Paul Tillich inspired concept on religion based on the idea that 'religion' basically is about existential questions and answers (ultimate concerns) and is an ontological fact for all humans. 
critical thinking skills. My research shows that this absence of theoretical and methodological aspects also applies to textbooks and the intended teaching of the teachers. Some teaching guidelines to textbooks do introduce theories on religious topics, such as rituals; however, they do not show how the pupils can use this (Kjeldsen, 2016, p. 272). This absence also characterises the national curriculum for RE in the elementary and lower-secondary school in Norway. After the end of $4^{\text {th }}$ grade, the pupils shall be able to, inter alia:

- Talk about the content and listen to the central narratives of the Bible, the Torah, and the Quran.

- Describe Christian churches.

- Know Christian psalms.

- Talk about different religions, religious practices, and ethical and existential issues.

- Recognise religious and humanistic art and be able to use aesthetic expressions from religions and humanism.

(The Norwegian Ministry of Education, 2015, author's translation).

After the end of the $7^{\text {th }}$ and $10^{\text {th }}$ grades, the content is much the same, except that pupils shall be able to explain or account for the abovementioned aspects, talk about and explain the concept of religion, and discuss questions related to religion, culture, and society. In addition to these few aims, the curriculum does not mention theoretical and methodological issues or skills. ${ }^{10}$ Therefore, a crucial question to ask educational authorities is why RE is different compared to other subjects. Why is it that pupils shall learn how to read and write in different languages, learn mathematical skills and how to analyse historical texts, and similar in their first years of school, but not learn how to use methodological and theoretical approaches pertaining to the academic study of religion(s) and develop analytical critical thinking skills in RE? As mentioned above, this difference does not seem to be based on solid pedagogical and educational grounds. The national curriculum for RE in Swedish elementary schools may serve as a good example of how a more analytical and critical thinking approach is possible also in the elementary and lower-secondary schools. It states that RE shall enable pupils to interpret cultural expressions connected to religious traditions and gain competencies about how to investigate primary sources and issues in society related to religions and other worldviews from an analytical-critical perspective. The guideline further stresses that RE should contribute to the development of academic and analytical skills, including the historical criticism of sources. In addition, the pupils should be

10 For an overview on RE in Norway, see Andreassen, 2013. 
able to identify how religious motifs or stereotypes may be found in different political and public statements (The Swedish Ministry of Education, 2017, 2018, author's translation $)^{11}$.

\section{Concluding remarks}

The various models of RE presently in place in Europe, the different didactic approaches to RE, and research into RE all clearly demonstrate that RE in many countries is conceived or thought of as a unique or extra-ordinary subject. This is evident, even though what Jean-Paul Willaime (2007) calls a 'Européanisation' of challenges, namely globalisation, pluralisation and migration are challenging the various models of RE and ideas about national and/or European citizenship, 'cultural identity and heritage' and social cohesion. Due to these challenges, trans-national political organisations, RE teachers, researchers and pupils seem to agree on the need to teach about different religions in schools in a nuanced, pluralistic and impartial way as part of or as a supplement to the existing RE. At the same time, many politicians and people involved in $\mathrm{RE}$ also assert that RE still should contribute to various extra-academic aims and include some form of learning from religion(s) (and particularly the majority religion). However, $\mathrm{RE}$ research conducted by the scholars here mentioned shows that these ideas on RE are based on political, ideological and/or religious interest, and imply various (unintended) problems. Not only seen from a studyof-religion(s), but also from a critical educational, pedagogical and democratic perspective. These problematic aspects, I argue, show the relevance of a studyof-religion(s) based approach to RE.

Moreover, critical educational and pedagogical thinkers such as Benner, Biesta, and Thomas Ziehe (2004), further support this approach. They argue that democratic and pluralistic societies need individuals who think critically and have the ability to participate in democratic discussions and processes and, possibly, change the status quo. In addition, Ziehe also asserts that schools shall introduce knowledge and work methods that are unfamiliar to pupils and challenge what they know and encounter in their everyday lives and wider society. This, he finds even more critical today, given the growing public opposition to scientific-based knowledge and a general acceptance of everyday knowledge and subjective opinions as the most important forms of guidance in both private and public matters (Ziehe, 2004). A study-of-religion(s) approach to RE is in line with this thinking, and can, as put forward by RE scholars of the academic study of religions, contribute to the development of future citizens with relevant

11 For an overview on RE in Sweden, see Berglund, 2013. 
and needed analytical and critical thinking competencies and knowledge on religion(s) and society.

\section{References}

Alberts, W. (2007). Integrative religious education in Europe: A study-of-religions approach. Berlin: de Gruyter.

Alberts, W. (2008). Didactics of the study of religions. Numen 55(2), 300-334.

Alberts, W. (2010). The academic study of religions and integrative religious education in Europe. British Journal of Religious Education, 32(3), 275-29o.

Andreassen, B. O. (2008). 'Et ordinoert fag i sarklasse': en analyse av fagdidaktiske perspektiver $i$ innføringsbøker i religionsdidaktikk [A special subject: An analysis of didactic perspectives in didactic teaching books]. (Unpublished doctoral dissertation). University of Tromsø, Tromsø.

Andreassen, B. O. (2013). Religion education in Norway: Tension or harmony between human rights and Christian cultural heritage? Temenos. Nordic Journal of Comparative Religion, 49(2), 137-164. Andreassen, B. O. (2014). Christianity as culture and religions as religions. An analysis of the core curriculum as framework for Norwegian RE. British Journal of Religious Education, 36(3), 265-281. Andreassen, B. O. (2016). Religionsdidaktikk. En innføring [Didactics of religion. An introduction] (2nd ed.). Oslo: Universitetsforlaget.

Asad, T. (1993). Genealogies of religion. Discipline and reasons of power in Christianity and Islam. Baltimore \& London, UK: The John Hopkins University Press.

Benner, D. (2005). Tekster til dannelsesfilosofi: mellem etik, paedagogik og politik [Selected texts on theories of Bildung: Between ethics, pedagogy and politics]. Aarhus, DK: Klim.

Berglund, J. (2013). Swedish religion education: Objective but marinated in Lutheran Protestantism? Temenos. Nordic Journal of Comparative Religion, 49(2), 165-184.

Biesta, G. (2013). Demokratiloring i skole og samfund: uddannelse, livslang loering og medborgerskabets politik [Learning democracy in school and society]. Aarhus, DK: Klim.

Buchardt, M. (2014). Religion and culture as identity politics in the classroom. Münster: Waxmann Verlag.

Böwadt, P. R. (2009). The courage to be: The impact of Lebensphilosophie on Danish RE. British Journal of Religious Education, 31(1), 29-39.

Conroy, J. C., Lundie, C., Baumfield, V., Barnes, L. P., Gallagher, T. et al. (2013). Does religious education work? A multi-dimensional investigation. London, UK \& New York, NY: Bloomsbury Academic.

Council of Europe. (2002). Recommendation Rec (2002)12 of the Committee of Ministers to member states on education for democratic citizenship. Retrieved from www.coe.int Council of Europe. (2008a). White Paper on Intercultural Dialogue. Retrieved from www.coe.int Council of Europe. (2008b). Recommendation CM/Rec (2008)12 of the Committee of Ministers to member states on the dimension of religions and non-religious convictions within intercultural 
education. Retrieved from www.coe.int

Fancourt, N. (2005). Challenges for self-assessment in religious education. British Journal of Religious Education, 27(2), 115-125.

Feldt, L., \& Høgel, C. (2018). Reframing authority - The role of media and materiality. In L. Feldt \&

C. Høgel (Eds.), Reframing authority: The role of media and materiality (pp. 1-16). Sheffield: Equinox Publishing.

Frank, K. (2013). Wie implementiert man einen religionskundlichen Unterricht? Analysen und Entwicklungen [How to implement a study-of-religions based religious education? Analysis and developments] In A. Hindriksen (Ed.), Religionspädagogik zwischen religionswissenschaftlichen Erwartungen und pädagogischen Ansprüchen (pp. 61-103). Bremen: Universität Bremen. Retrieved from http://nbn-resolving.de/urn:nbn:de:gbv:46-00103350-11

Frank, K. (2014). Die Konstruktion von religiösem und säkularem Wissen im schulischen Religionsunterricht [Construction of religious and secular knowledge in religious education in schools]. Zürich: Universität Zürich. Retrieved from http://www.religionswissenschaft.uzh.ch/ seminar/personenliste/frank/frank_konstruktion_2014.pdf

Frank, K., \& Christoph, B. (2008). Religious education in Switzerland as a field of work for the study of religions: Empirical results and theoretical reflections. Numen, 55(2), 183-217.

Geertz, A. W. (2000). Global perspectives on methodology in the study of religion. In A. W. Geertz \& R. T. McCutcheon (Eds.), Perspectives on method \& theory in the study of religion (pp. 49-73). Leiden: Brill.

Geertz, A. W. (2015). Primitivisme og postkolonial kritik i studiet af oprindelige folks religioner [Primitivism and post-colonical critique in the study of indigenous people]. In A. W. Geertz \& T. Jensen (Eds.), Religionsforskningen før og nu II. Nyere tid (pp. 215-245). Copenhagen: Gyldendal. Geertz, A. W., \& McCutcheon, R. T. (2000). The role of method and theory in the IAHR. In A. W. Geertz \& R. T. McCutcheon (Eds.), Perspectives on method \& theory in the study of religion (pp. 3-37). Leiden: Brill.

Gilhus, I. S., \& Mikaelsson, L. (2001). Nytt blikk på religion: studiet av religion i dag [New eyes on religion: The study of religions today]. Oslo: Pax.

Hughes, A. W. (2012). Abrahamic religions: On the uses and abuses of history: Oxford Scholarship Online.

Ipgrave, J. (2012). Three challenges to the common understanding of the role of RE in promoting religious tolerance. REsource. The Journal of the National Association of Teachers of Religious Education, 35(1), 10-13.

Jackson, R. (2008). Teaching about religions in the public sphere: European policy initiatives and the interpretive approach. Numen, 55(2), 151-182.

Jackson, R. (2009). The Council of Europe and education about religious diversity. British Journal of Religious Education, 31(2), 85-90.

Jackson, R. (2014). Signposts - Policy and practice for teaching about religions and non-religious worldviews in intercultural education. Council of Europe Publishing. Retrieved from https://www. 
coe.int/en/web/education/newsroom/-/asset_publisher/ESahKwOXlcQ2/content/signpostspolicy-and-practice-for-teaching-about-religions-and-non-religious-world-views-in-interculturaleducation?inheritRedirect $=$ false Jensen, J. S. (2003). The study of religion in a new key: Theoretical and philosophical soundings in the comparative and general study of religion. Aarhus: Aarhus University Press.

Jensen, T. (2005). European and Danish religious education: Human rights, the secular state, and ,rethinking religious education and plurality. Religion \& Education, 32(1), 60-78.

Jensen, T. (2008). RS based RE in public schools: A must for a secular state. Numen, 55(2), 123-150.

Jensen, T. (2011). Why religion education, as a matter of course, ought to be part of the public school curriculum. In L. Loobuyck \& P. Franken (Eds.), Religious education in a plural, secularized society. A paradigm shift (pp. 131-149). Münster: Waxmann Verlag. Jensen, T. (2013). A battlefield in the culture wars: Religious education in Danish elementary school 1989-2011. In A. Jödicke (Ed.), Religious education politics, the state, and society (pp. 25-49). Würzburg: Ergon Verlag. Jensen, T. (2014). L'enseignement de la religion au Danemark: les résponses récentes à des défis européens communs [RE in Denmark: Recent responses to common European challenges]. In J.-P. Willaime (Ed.), Le défi de l'enseignement des faits religieux à l'école: résponses européennes et québécoises, (pp. 43-66). Paris: Riveneuvre Jensen, T. (2015). Religious education (RE) in other kinds of bordertowns: Denmark as an extreme and exemplary case. In J. Berglund, T. Lundén, \& P. Strandbring (Eds.), Crossings and crosses (pp. 213-238). Bosten/Berlin: Walter de Gruyter. Jensen, T., \& Kjeldsen, K. (2013). RE in Denmark - Political and professional discourses and debates, past and present. Temenos. Nordic Journal of Comparative Religion, 49(2), 185-224. Jensen, T., \& Kjeldsen, K. (2014). Baseline study. European projects and recommendations involving religious education (RE). IERS Project. intercultural education through religious studies, lifelong learning program (LLP) of the European Union. Retrieved from http://iers.unive.it/files/2014/03/ Baseline_Study-European-projects-and-recommendations-involving-RE.pdf Jödicke, A. (2013). Introduction. In A. Jödicke (Ed.), Religious education politics, the state, and society (pp. 7-22). Würzburg: Ergon Verlag.

Keast, J. (Ed.) (2007). Religious diversity and intercultural education: A reference book for schools. Strasbourg: Council of Europe Publishing. Retrieved from https://book.coe.int/eur/en/humanrights-education-intercultural-education/3692-religious-diversity-and-intercultural-education-areference-book-for-schools.html

King, R. (1999). Orientalism and religion: Postcolonial theory, India and 'the mystic east'. Florence: Routledge.

Kjeldsen, K. (2016). Kristendom i folkeskolens religionsfag. Politiske og faglige diskussioner, reproesentation og didaktisering [The status and function of Christianity in religion education in the Danish public school. Political and professional debates, representation and didactic approaches]. (Unpublished doctoral dissertation). The Faculty of Humanities, University of Southern Denmark, 
Odense.

Kjeldsen, K. (2019). Et kristent funderet religionsfag. En undersøgelse af kristendoms sarlige status $i$ skolen [A Christian based religious education. A study on the special status of Christianity in the School]. Copenhagen: Unge Pædagoger.

Lincoln, B. (1989). Discourse and the construction of society. Comparative studies of myth, ritual, and classification. New York, NY: Oxford University Press.

Lincoln, B. (2006). Holy terrors: Thinking about religion after September 11. Chicago, IL: University of Chicago Press.

Luther, H. M. (2000). Secular theory and the academic study of religion. In T. Jensen \& M. Rothstein (Eds.), Secular theories on religion. current perspectives (pp. 137-148). Copenhagen: Museum Tusculanum Press.

Masuzawa, T. (2005). The invention of world religions. Chicago, IL: University of Chicago Press. McCuthenon, R. T. (2000). Critics not caretakers: The scholar of religion as public intellectual. In T. Jensen \& M. Rothstein (Eds.), Secular Theories on religion. Current perspectives (pp.167-181). Copenhagen: Museum Tusculanum Press.

McCuthenon, R. T. (2015). The category 'religion' in recent publications: Twenty years later. Numen, 62(1), 119-141.

Miedema, S., Schreiner, P., Skeie, G., \& Jackson, R. (2004). The European network for religious education through contextual approaches (ENRECA): Its Policy and aims. Panorama: International Journal of Comparative Religious Education and Values, 16, 10-14.

Mikaelsson, L. (2004). Gendering the history of religions. In P. Antes, A. W. Geertz, \& Randi R. W. (Eds.), New approaches to the study of religion. Volume 1: Regional, critical, and historical approaches (pp. 295-315). Berlin \& New York, NY: Walter de Gruyter.

Morgan, D. (2010). Introduction. The matter of belief. In D. Morgan (Ed.), Religion and material culture. The matter of belief (pp. 1-17). London, UK \& New York, NY: Routledge.

Mortensen, C. B., Rydahl, J., \& Tunebjerg, M. 2002. Liv og religion 3 Laererens Bog [Life and religion.

Guide for teachers]. Copenhagen: Gyldendal.

OSCE (Organization for Security and Co-operation in Europe). (2007). The Toledo guiding principles on teaching about religion or belief in public schools. Retrieved from www.osce.org

Paden, W. E. (2004). Comparison in the study of religion. In P. Antes, A. W. Geertz, \& R. Randi (Eds.), New approaches to the study of religion. Textual, comparative, sociological and cognitive approaches. (Vol. 2, pp. 77-92). Berlin \& New York, NY: Walter de Gruyter.

Said, E. (2003). Orientalism (3rd ed.). London, UK: Penguin Books.

Sjöborg, A. (2013). Religious education and intercultural understanding: Examining the role of religiosity for upper secondary students' attitudes towards RE. British Journal of Religious Education, (35) $1,36-54$.

Skolverket. (2017). Kommentarmaterial till kursplanen i religionskunskap [National guidelines for religion education].

Skolverket. (2018). Kursplan. Religionskunnskap [National curricula for religion education]. 
Teece, G. (2008). Learning from religions as 'skillful means': A contribution to the debate about the identity of religious education. British Journal of Religious Education 3o(3), 187-198.

Teece, G. (2010). Is it learning about and from religions, religion or religious education? And is it any wonder some teachers don't get it? British Journal of Religious Education 32(2), 93-103.

Tillich, P. (1966 [1951]). Systematic theology (Vol. 1). Chicago, IL: The University of Chicago Press. Undervisningsministeriet. (2019a). Foelles Mål. Historie [National curricula for History].

Undervisningsministeriet. (2019b). Folles Mål. Kristendomskundskab [National curricula for 'Knowledge about Christianity'].

United Nations. (2006). Alliances of civilizations. Retrieved from http://www.un.org/en/index.html Utdanningsdirektoratiet. (2015). Loereplan i kristendom, religion, livssyn og etikk (KRLE) [National curricula for 'Christianity, religion, worldviews and ethics'].

Weisse, W. (2007). The European research project on religion and education REDCo. An Introduction. In R. Jackson, S. Miedema, W. Weisse, \& J. P. Williame (Eds.), Religion and education in Europe. Developments, contexts and debates (pp. 9-26). Münster: Waxmann Verlag.

Wiebe, D. (1984). The Failure of nerve in the academic study of religion. Studies of Religion 13(4), 401-422

Willaime, J-P. (2007). Different models for religion and education in Europe. In R. Jackson, S. Miedema, W. Weisse, \& J. P. Williame (Eds.), Religion and education in Europe. Developments, contexts and debates (pp. 57-66). Münster: Waxmann.

Ziehe, T. (2004). Øer af intensitet i et hav af rutine: nye tekster om ungdom, skole og kultur [New texts on youth, school and culture]. Copenhagen, DK: Politisk Revy.

\section{Biographical note}

KARNA KJELdsen, PhD, is an assistant professor in the field of didactics of the study of religion(s) at the Centre for Teaching and Learning, Absalon University College, Denmark. Her research interests include politics on religion(s), migration, citizenship and religious education, the representation and teaching of religions, theoretical and methodological issues in the study of religions and religious education, and developing and promoting a study-of-religion(s) based approach to religion education. 